\title{
Polanyi, markets and environmental protection
}

\author{
Arild Vatn (arild.vatn@nmbu.no) \\ Norwegian University of Life Sciences, Norway
}

Carbon trading has been envisioned as a kind of Polanyian fictitious commodification facilitating capital accumulation (e.g., Lohmann, 2012; Büscher \& Fletcher, 2015). In his paper 'The EU Emissions Trading Scheme: Protection via Commodification?' Christopher M. Rea asks if this is a reasonable understanding. He rather concludes "that market-oriented schemes like the EU ETS are better characterized as a Polanyian countermovement that is, in fact, helping to 're-embed' the European economy in more ecologically sustainable relationships with nature" (Rea, 2019, 48).

While being a somewhat provocative conclusion, I agree that there is a certain validity to the claim. Polanyi emphasized that labour and land was life itself, not produced for trade. Hence, commodifying them and "leaving the fate and soil and people to the market would be tantamount to annihilating them. Accordingly, the countermove consisted in checking the action of the market in the respect to the factors of production, labour, and land" (Polanyi, 1944, 131). How could markets then be part of a countermovement? Before I discuss the claim, I will briefly visit the idea that carbon trading, like other 'neoliberal' conservation efforts, is part of a new wave of expansion for capital accumulation - i.e., dis-embedding.

Büscher and Fletcher (2015) have coined the expression 'Accumulation by conservation' referring to both Marxian and Polanyian perspectives. This form of conservation is "a mode of accumulation that takes the negative environmental contradictions of contemporary capitalism as its departure for a newfound 'sustainable' model of accumulation for the future" $(2015,273)$. Payments for ecosystem services (PES), biodiversity offsets/habitat banking and carbon trading are all used as examples. Certainly, these developments open up some new frontiers for accumulation, not least for the financial sector (e.g., Sullivan, 2013). Moreover, forms of 'green grabbing' - typically established under contexts of legal pluralism - may imply commodification of land in the standard Polanyian sense with the aim of capital accumulation. Despite this, one may question the basis for seeing 'accumulation by conservation' as a great new frontier.

Generally, carbon trading and biodiversity offsets are based on setting limits for use of natural resources. In the case of carbon trading, the basis is a cap on carbon emissions largely a cap on how much fossil fuels that can be extracted in a given period of time. Certainly, that limits instead of enhances the possibilities for capital accumulations. This is the effect of any limit on (natural) resource use, and industry understood this - being evident not least in all disinformation and lobbying against any regulations on fossil fuel use (Hoggan \& Littlemoore, 2009; Oreskes \& Conway, 2010). Similarly, we observe lobbying regarding the rules on carbon trading to make them as 'industry friendly' as possible (Helm, 2010). In the case of PES, there are no limits set. Hence, one could believe that there was more gain to make. However, neither industry nor financial actors are interested; $99 \%$ of 
the money used for PES comes from the public purse (Vatn, 2015a). This is simply so, because there is little gain for industry.

Nevertheless, turning it all around and claiming that 'more market' can be a kind of Polanyian countermovement, is going much further than my critique of 'conservation as accumulation'. Rea's argument is basically built on the observation that carbon trading in the form of EU ETS is a way to protect our climate. It has not been especially effective due to various faults of the system. However, it is a kind of countermovement reacting to the disembedding of markets that, according to Rea, may themselves include market mechanisms. He concludes, "Entitlements to pollute, as traded under the EU ETS, ... are not Polanyian fictitious commodities. These commodified entitlements to pollute are instead fictitiously fabricated - socially and administratively constructed - real commodities (at least in a Polanyian sense): they are fabricated for exchange in markets but are not, in any direct sense, foundational elements of economic (or ecological) life" (Rea, 2019, 66).

Thinking this through raises some issues. First, fossil fuels are literally 'land' - the result of biological processing of soil and plants over millions of years. Hence, maybe we have to term such fuels as fictitious commodities? They are at least not originally produced for trade. That is showing a limitation in Polanyi's own thinking. No natural resources are produced as commodities. So, all commodities may have to be seen as fictitious as there are natural resources involved in making any good. Secondly, aren't carbon caps in reality just caps on how much fossil fuels are allowed to be extracted/used? Leaving aside carbon capture and storage, carbon quotas are in practice formulated on the basis of how much fossil fuels is bought/used. The cap is presented as a cap on emissions, but no emissions are measured. What is measured is the trade of fossil fuels, next with a calculation of how much $\mathrm{CO}_{2}$ it represents as emissions when used. Therefore, I agree that to the extent fossil fuels are real commodities, emission rights are too. However, one may question if such fuel is not a foundational element of economic life, hence, the fictitiousness slips in through the 'back door'.

Second, there has been a series of limitations and problems with carbon trading. Rea is well aware of these. In the case of the EU ETS system, it regards not least over allocation of quotas and problems with fraud - see also Helm (2010). While, the net effect of carbon trading is a limitation on capital accumulation, there are moreover opportunities for certain sections of business to gain from 'markets for conservation'. This is especially the case for financial actors and actors that 'live off' the trading itself. Economic transactions are themselves a basis for making profits and those that aspire to become 'middlemen' in, for example, carbon trading, have been very actively engaged in pushing for such systems and influencing their set-up (Lohmann, 2012; Sullivan, 2013). Notably, in the case of carbon trading, neither buyers nor sellers are really interested in the commodity. They are after the CERs (certified emission reductions). While this creates demanding incentive problems in general, the problems have been extra visible in case of trading related to carbon storage in forests and other $\mathrm{CDM}^{1}$ type projects in the Global South. There are several reasons for that. One regards the fact that cheating is easier when the trade is delinked from fossil fuels as a standardized commodity. Another concerns the role financialization has played in case of these products (Lohmann, 2012).

The main issue, I think, regards defining what it means to embed. While I am sympathetic to Rea's somewhat provocative argument, I am not sure if it carries all the way through.

${ }^{1}$ Clean Development Mechanism 
What did Polanyi mean by embedding? Actually, he only used the concept twice in 'The Great Transformation'. Let me cite from both passages:

"... the motive of truck or barter, is capable of creating a specific institution, namely, the market. Ultimately, that is why the control of the economic system by the market is of overwhelming consequence to the whole organization of society: it means no less than the running of society as an adjunct to the market. Instead of economy being embedded in social relations, social relations are embedded in the economic system... For once the economic system is organized in separate institutions, based on specific motives and conferring a special status, society must be shaped in such a manner as to allow that system to function according to its own laws. This is the meaning of the familiar assertion that a market economy can function only in a market society" (Polanyi, 1944, 57).

Next, a few pages later: "In the vast ancient systems of redistribution, acts of barter as well as local markets were a usual, but no more than a subordinate trait. The same is true where reciprocity rules; acts of barter are here usually embedded in long-range relations implying trust and confidence, a situation which tends to obliterate the bilateral character of the transaction" (Polanyi, 1944, 61).

These passages - as well as the whole book - point towards embedding being more than just avoidance of fictitious commodification. Rea himself seems aware when he states that while "environmental protection via commodification might help to produce moderate levels of ecological embeddedness... growing ecological crises demand much more rapid and far-reaching social and economic transformations" (Rea, 2019, 67). This may point towards a re-embedding that is more in line with the Polanyian perspective than carbon trading.

Over the last few decennia, a substantial literature has evolved showing that human action may be based on different types of rationalities and that markets and money themselves are institutions that strengthen the focus on individual gain as opposed to collectively sound outcomes - see e.g., Vohs et al. (2006); Hodgson (2007); Bowles (2008); Gneezy et al. (2011), Vatn (2015b). This literature points towards the implications of institutional contexts for the kind of motivation that inspires action. The distinction between individual and social rationality growing out of this research may be seen as an extension of Polanyi. It implies that policy instruments like cap-and-trade not only act as external incentive structures. They also influence the way issues are perceived - what they are thought to be about. Therefore, while cap-and-trade systems may be effective to the extent the rules set are 'tight' enough, they are internally conflictual as they try to solve a tremendous collective challenge by appealing to self-interest. In my mind, it is here the fundamental limit of markets and dis-embedding lies.

\section{References}

Bowles, S. (2008). Policies designed for self-interested citizens may undermine 'the moral sentiments': evidence from economic experiments. Science, 320(5883), 1605-9.

Büscher, B. \& Fletcher, R. (2015). Accumulation by conservation. New Political Economy, 20(2), 273-298

Gneezy, U., Meier, S. \& Rey-Biel, P. (2011). When and why incentives (don't) work to modify behavior. Journal of Economic Perspectives, 25(4), 191-210. 
Helm, D. (2010). Government failure and rent-seeking and capture: The design of climate change policy', Oxford Review of Economic Policy, 26(2), 182-196.

Hodgson, G.M. (2007). The revival of veblenian institutional economics. Journal of Economic Issues, XLI(2), 325-40.

Hoggan, J. and Littlemoore, R. (2009). Climate cover up. The crusade to deny global warming. Vancouver: Greystone Books.

Lohmann. L. (2012). Financialization, commodification and carbon: The contradictions of neoliberal policy. Socialist register, 2012, 85-107.

Oreskes, N. \& Conway, E.M. (2010). Merchants of doubt. New York: Bloomsbury Press.

Polanyi, K., [1944] (1957). The Great Transformation. The political and economic origins of our time. Boston, MA: Beacon Press.

Rea, C. M. (2019). The EU Emissions Trading Scheme: Protection via commodification? Culture, Practice \& Europeanization, 4(1), 48-73.

Sullivan, S. (2013). Banking nature? The spectacular financialisation of environmental conservation. Antipode, 45, 198-217.

Vatn, A. (2015a). Markets in environmental governance. From theory to practice. Ecological Economics, 117, 225-233.

Vatn, A. (2015b). Environmental governance. Institutions, policies and action. Cheltenham: Edward Elgar.

Vohs, K.D., Mead, N.L. \& Goode, M.R. (2006). The psychological consequences of money. Science, 314(5802), 1154-6. 